ORIGINAL ARTICLE

\title{
Anthropometric Parameters: Obesity and Metabolic Risks for Non-communicable Diseases among Adolescent Swimmers
}

\author{
SE Beckford, MC Webb
}

\begin{abstract}
Objective: To assess obesity and metabolic risks for non-communicable diseases among adolescent swimmers.

Methods: A cohort of 220 swimmers was selected at their respective swimming clubs via quota sampling and measured using various anthropometric parameters, which were then compared with standard cut-off points for the various age groups.

Results: The mean body mass index (BMI) was $21.23 \pm 3.85 \mathrm{~kg} / \mathrm{m}^{2}$, the mean waist circumference was $69.8 \pm 8.08 \mathrm{~cm}$, and the mean body fat percentage was $21.20 \pm 9.27 \%$. These mean body composition variables fell within their respective recommended ranges according to the cut-off points. Height $(\mathrm{p}<0.001)$, weight $(\mathrm{p}<0.011)$, mid-upper arm circumference $[M U A C](\mathrm{p}=0.035)$ and visceral fat $(\mathrm{p}=0.033)$ were statistically significant when compared between males and females. Chi-square analysis revealed that gender was statistically significantly associated with waist-to-hip ratio [WHR] $(\mathrm{p}<0.001)$ and body fat percentage [BFP] $(\mathrm{p}=0.003)$, while BFP was statistically significantly associated with BMI $(\mathrm{p}<0.001)$, waist circumference $(\mathrm{p}<0.001)$, WHR $(\mathrm{p}=0.026)$, MUAC $(\mathrm{p}<0.001)$ and skeletal muscle mass $(\mathrm{p}<0.001)$.

Conclusion: The swimmers had an overall healthy body composition and were at low risk for developing non-communicable diseases. We recommend that Trinidad and Tobago develop anthropometric cut-off points for athletes and non-athletes.
\end{abstract}

Keywords: Adolescents, anthropometric, metabolic risks, swimmers

\section{Parámetros antropométricos: obesidad y riesgos metabólicos de las enfermedades no transmisibles entre los nadadores adolescentes}

\author{
SE Beckford, MC Webb
}

\begin{abstract}
RESUMEN
Objetivo: Evaluar la obesidad y el riesgo metabólicos para no-enfermedades transmisibles entre los nadadores adolescentes.

Métodos: Una cohorte de 220 nadadores fue seleccionada mediante muestreo de cuotas en sus respectivos clubes de natación, y sometida a mediciones utilizando varios parámetros antropométricos, que fueron luego comparados con puntos límites estándar para los distintos grupos etarios.
\end{abstract}

From: Department of Agricultural Economics and Extension, Faculty of Food and Agriculture, The University of the West Indies, St Augustine, Trinidad and Tobago, West Indies.
Correspondence: Dr M Webb, Room 25, Dudley Huggins Building, Department of Agricultural Economics and Extension, Faculty of Food and Agriculture, The University of the West Indies, St Augustine, Trinidad and Tobago, West Indies. Email: marquitta. webb@sta.uwi.edu 
Resultados: El índice de masa corporal (IMC) promedio fue $21.23 \pm 3.85 \mathrm{~kg} / \mathrm{m}^{2}$, la circunferencia promedio de la cintura fue $69.8 \pm 8.08 \mathrm{~cm}$, y el porciento de grasa corporal promedio fue de $21.20 \pm 9.27 \%$. Estas variables promedio de la composición corporal estuvieron dentro de los rangos recomendados de acuerdo con los puntos límites. La altura ( $\mathrm{p}<0.001$ ), el peso $(\mathrm{p}<0.011)$, la circunferencia braquial medio-superior $[C B M S](\mathrm{p}=0.035)$, y la grasa visceral $(\mathrm{p}=0.033)$ fueron estadísticamente significativas cuando se compararon hembras $y$ varones. El análisis de chi-cuadrado reveló que el género se hallaba significativamente asociado estadísticamente con el indice cintura-cadera [ICC] $(\mathrm{p}<0.001)$ y el porciento de grasa corporal $[P G C](\mathrm{p}=0.003)$, mientras que PGC se hallaba estadisticamente significativamente asociado con el IMC $(\mathrm{p}<0.001)$, el indice cintura-cadera [ICC] $(\mathrm{p}<0.001)$, la circunferencia de la cintura $(\mathrm{p}<0.001)$, el ICC $(\mathrm{p}=0.026), C B M S(\mathrm{p}<0.001)$, y la masa muscular esquelética $(\mathrm{p}<0.001)$.

Conclusión: Los nadadores tenían una composición corporal sana en general y presentaban bajo riesgo de desarrollar enfermedades no transmisibles. Recomendamos que Trinidad y Tobago desarrolle puntos límites antropométricos tanto para los deportistas como para los no deportistas.

Palabras clave: Adolescentes, antropométricos, riesgos metabólicos, nadadores

West Indian Med J 2018; 67 (1): 32

\section{INTRODUCTION}

The obesity epidemic is a critical public health challenge of the twenty-first century (1-3). According to the Centers for Disease Control and Prevention, United States of America (USA), more than one-third (34.9\% or over 78.6 million) of the adults in the USA and $17 \%(12.7$ million) of the children and adolescents aged 2-19 years in the USA were obese (4-6). This pandemic among adults appears to be foreshadowing a similar problem in children. The prevalence of obesity has doubled in children and tripled in adolescents over the last three decades and is a major health concern $(7,8)$. Children in the USA are not alone - rapidly rising rates of obesity threaten the health of an alarming number of children around the globe (2). Globally, an estimated 170 million children (aged below 18 years) were estimated to be overweight (9). Similarly, in the Caribbean region, there is a high incidence of overweight and obesity among young children and adolescents (10). The highest prevalence of childhood overweight is in upper- and middle-income countries and, when taken as a group, low-income countries have the lowest prevalence rate (2). However, overweight is rising in almost all countries, with prevalence rates growing fastest in lower- and middle-income countries (2).

Obesity has serious physical, psychological and social consequences. Individuals who are obese, defined as having a body mass index (BMI) of $\geq 30 \mathrm{~kg} / \mathrm{m}^{2}$, are at greater risk of suffering from non-communicable diseases (NCDs), such as heart disease, hypertension, diabetes mellitus, breast cancer and colon cancer (11-13). Obese as compared to non-obese children and adolescents are more likely to become obese as adults and are at risk for health problems during their youth and adulthood (14-16). During their youth, obese children and adolescents are more likely to have risk factors associated with cardiovascular disease, such as hypertension, hypercholesterolaemia, hyperlipidaemia and Type 2 diabetes, which were once seen only in adults (11-13, 17). Moreover, in children and adolescents, overweight and obesity are associated with significant reductions in quality of life $(18,19)$. Given the high prevalence and the known long-term effects of childhood overweight, there is an urgent need for the detection of obesity and its co-morbidities during childhood and adolescence. The prevention of NCDs is vital in children and adolescents as this helps to lay the foundation for the development of healthy lifestyles throughout adulthood (20).

In diagnosing obesity and metabolic risks, individualized assessments of body composition are necessary to improve fitness and maintain health (21). Body composition is influenced by factors such as age, gender, race, genes, physical activity, diet, the environment and presence of disease (22). Sudden changes in body composition may be an indication of a health problem (23). Studies have used various direct and indirect 
anthropometric parameters to assess the nutritional status of children and adolescents (24-27). Large multinational studies, such as International Day for the Evaluation of Abdominal Obesity (28), INTERHEART (29), European Prospective Investigation into Cancer and Nutrition (30) and the US Cancer Prevention Study II Nutrition Cohort (31), have confirmed that measurement of abdominal obesity and central fat accumulation is an important tool in assessing risk of heart disease, risk of developing Type 2 diabetes and risk of death. Waist circumference (WC), skinfold thickness and mid-upper arm circumference (MUAC) are the indirect methods used to screen children and adolescents for obesity (32, 33). Body mass index is recognized as the gold standard for identifying individuals at increased risk of obesityrelated co-morbidities (34). Epidemiologic studies have demonstrated a direct correlation between BMI and the risk of adiposity-related adverse health outcomes and mortality rate $(35,36)$. However, BMI is simply a ratio of weight in relation to height and is not a direct measurement of body fat. Hence, BMI provides no information about the distribution of body fat. In contrast, the measurement of WC provides information regarding fat topography. Therefore, WC is a good indicator of highrisk intra-abdominal or visceral fat accumulation and a good indicator of risk for obesity and its co-morbidities (34). Since WC correlates with abdominal fat mass (37) and is associated with hypertension, diabetes, coronary heart disease and dyslipidaemia (34-38), it is used as a marker for abdominal fat mass $(34,37)$. Mid-upper arm circumference is another indicator of obesity and was reported to reflect body fat tissue closely $(33,39)$. In light of the worldwide prevalence and importance of detecting NCDs in early life, this study assessed obesity and metabolic risks for NCDs among adolescent swimmers using anthropometric parameters.

\section{SUBJECTS AND METHODS}

\section{Participants}

Swimmers were recruited from private swimming clubs registered with the Amateur Swimming Association of Trinidad and Tobago via quota sampling. At the time of data collection, participants were registered with and trained by a competitive club. A total of 220 swimmers participated in the study. Ethical approval for the study was obtained from the Campus Research Ethics Committee of The University of the West Indies, St Augustine, Trinidad and Tobago. Additionally, consistent with ethical conduct for research involving human participants, informed consent in writing was obtained from participants and/or their parents/guardians.

\section{Procedure}

The following anthropometric parameters were collected: height, weight, BMI, body fat percentage (BFP), MUAC, WC, hip circumference (HC), skeletal muscle mass (SMM), visceral fat (VF) and waist-to-hip ratio (WHR). Trained professionals conducted all anthropometric measurements. Height and body weight were measured according to the protocol of the International Society for the Advancement of Kinanthropometry (40). Height was measured to the nearest $0.1 \mathrm{~cm}$ in bare feet with swimmers standing upright against a mounted stadiometer. Weight was measured to the nearest $0.1 \mathrm{~kg}$ with swimmers lightly dressed (swim suits or trunks) using a bioelectrical impedance analysis (BIA) scale (Omron Full Body Sensor Body Composition Monitor and Scale, Model HBF-510, Illinois, USA). Body fat percentage, VF, SMM and BMI were measured using the BIA scale. Waist circumference, $\mathrm{HC}$ and MUAC were measured using a non-stretch measuring tape. Waist circumference was measured to the nearest $0.1 \mathrm{~cm}$ at the minimal respiration (at the mid-point between the lowest rib and the top of the iliac crest). Hip circumference was measured to the nearest $0.1 \mathrm{~cm}$ over minimal clothing at the maximal extension of the buttocks (at the level of the greatest protrusion of the gluteal muscles). Mid-upper arm circumference was measured to the nearest $0.1 \mathrm{~cm}$ at the mid-point between the tip of the shoulder and the tip of the elbow (olecranon process and the acromion). Body mass indices were compared with the World Health Organization's (WHO) simplified field tables for BMI-for-age for girls and boys aged 5 to 19 years [percentiles] (41) and with WHO's BMI classification for adults (42). The WC cut-off points developed by Fernández et al (43) and the MUAC cut-off points developed by Mazicioğlu et al (33) were used to compare measurements. The International Obesity Task Force (IOTF) cut-off points for BFP were used in this study (44). The reference data of the manufacturer of the BIA scale used in this study were used for the classification of VF and SMM percentages (45).

\section{Statistical analysis}

The Statistical Package for Social Sciences (SPSS) for Mac, version 21.0 (SPSS Inc, 2012, Chicago, Illinois, USA) was used for the analyses. Data were analysed using descriptive statistics. The parametric t-test was 
applied to test significance levels at $p<0.05$ between genders, while Chi-square was used to determine associations between gender and anthropometric variables and between BFP and other anthropometric variables. The statistical significance was set at $p<0.05$.

\section{RESULTS}

The study sample comprised of 220 swimmers: 122 $(55.5 \%)$ were male and $98(44.5 \%)$ were female. The mean age of the swimmers was $14.56 \pm 2.54$ years. The majority of the swimmers were of mixed descent. The highest level of education attained by most swimmers was secondary school. The majority of the swimmers were in the age group of 15-17 years. Additionally, the majority of the swimmers (125 or 56.8\%) reported that they had never attended a nutrition class, course or seminar since starting to swim (Table 1).

The mean and standard deviations of the swimmers' anthropometric characteristics are presented in Table 2. The mean BMI was $21.2 \pm 3.85 \mathrm{~kg} / \mathrm{m}^{2}$ and fell between the $3^{\text {rd }}$ and $85^{\text {th }}$ percentiles for children. Statistical analyses showed that the male swimmers were significantly taller than their female counterparts $(p<0.001)$. They also had a statistically significantly higher weight $(p=0.011)$ and MUAC $(p=0.035)$ than the female swimmers. There were no statistically significant differences between the genders in the other variables.

Table 3 shows the classification of the swimmers based on cut-off points. According to BMI, 4 (1.9\%) swimmers were underweight, 39 (17.7\%) were overweight and $19(8.6 \%)$ were obese. Measurements of BFP placed $35(17.6 \%)$ swimmers in the 'under fat' category, 109 (55.1\%) 'normal fat' or optimal fat, 32 (16.2\%) 'over fat' and $22(11.1 \%)$ 'obese'. Based on WC for age, $215(97.8 \%)$ swimmers were classified as 'low risk' and $5(2.3 \%)$ as 'high risk'. For MUAC, only $24(10.9 \%)$ swimmers were classified as having a 'normal weight' while $196(89.1 \%)$ were classified as being 'overweight' or 'obese'.

Table 1: Demographic variables of the swimmers $(n=220)$

\begin{tabular}{llrr}
\hline Variable & Classification & n & \% \\
\hline Gender & Female & 98 & 44.5 \\
& Male & 122 & 55.5 \\
Ethnicity & African & 70 & 31.8 \\
& Indian & 11 & 5.0 \\
& Caucasian & 7 & 3.2 \\
& Asian & 3 & 1.4 \\
Age range (years) & Mixed & 129 & 58.6 \\
& $11-12$ & 61 & 27.7 \\
& $13-14$ & 59 & 26.8 \\
Highest level of education & $15-17$ & 70 & 31.8 \\
& $18-21$ & 30 & 13.6 \\
& Primary & 16 & 7.3 \\
& Secondary & 175 & 79.5 \\
& Tertiary & 29 & 13.2 \\
Number of nutrition classes/courses/ & None & 126 & 57.3 \\
seminars attended & $1-3$ & 76 & 34.5 \\
& 4 or more & 18 & 8.2 \\
\hline
\end{tabular}

Table 2: Anthropometric variables of the swimmers

\begin{tabular}{|c|c|c|c|c|}
\hline \multirow[t]{2}{*}{ Anthropometric variable } & \multicolumn{3}{|c|}{ Mean \pm standard deviation } & \multirow[t]{2}{*}{$p$-value } \\
\hline & Male $(n=122)$ & Female $(n=98)$ & Total $(n=220)$ & \\
\hline Age (years) & $14.9 \pm 2.67$ & $14.2 \pm 2.34$ & $14.5 \pm 2.54$ & \\
\hline Height (m) & $1.7 \pm 0.11$ & $1.6 \pm 0.072$ & $1.7 \pm 0.10$ & $<0.001^{*}$ \\
\hline Weight $(\mathrm{kg})$ & $61.7 \pm 15.68$ & $54.5 \pm 11.18$ & $58.5 \pm 14.28$ & $0.011^{*}$ \\
\hline Body mass index $\left(\mathrm{kg} / \mathrm{m}^{2}\right)$ & $21.5 \pm 3.91$ & $21.0 \pm 3.78$ & $21.2 \pm 3.85$ & 0.522 \\
\hline Waist circumference $(\mathrm{cm})$ & $71.4 \pm 8.17$ & $67.9 \pm 7.60$ & $69.8 \pm 8.08$ & 0.357 \\
\hline Hip circumference $(\mathrm{cm})$ & $88.6 \pm 9.88$ & $89.7 \pm 9.79$ & $89.1 \pm 9.84$ & 0.687 \\
\hline Mid-upper arm circumference $(\mathrm{cm})$ & $28.4 \pm 5.85$ & $26.3 \pm 3.50$ & $27.4 \pm 5.04$ & $0.035^{*}$ \\
\hline Waist-to-hip ratio $(\mathrm{cm})$ & $0.8 \pm 0.042$ & $0.8 \pm 0.043$ & $0.8 \pm 0.05$ & 0.243 \\
\hline Body fat percentage $(\%)^{b}$ & $15.7 \pm 6.93$ & $27.3 \pm 7.52$ & $21.2 \pm 9.27$ & 0.538 \\
\hline Visceral fat ${ }^{\mathrm{c}}$ & $5.3 \pm 3.29$ & $3.4 \pm 0.73$ & $4.8 \pm 2.90$ & $0.033^{*}$ \\
\hline Skeletal muscle mass $(\%)^{\mathrm{c}}$ & $41.4 \pm 3.60$ & $31.2 \pm 5.64$ & $38.3 \pm 6.36$ & 0.160 \\
\hline
\end{tabular}

${ }^{a} p$-values are for differences in the variables between male and female swimmers.

${ }^{\mathrm{b}}$ Body fat percentages were not obtained for 22 swimmers.

${ }^{c}$ Visceral fat and skeletal muscle mass percentage were obtained for only 30 swimmers.

${ }^{*} p<0.05$ 
Chi-square analysis revealed that gender was statistically significantly associated with WHR $(p<0.001)$ and BFP $[p=0.003]$ (Table 4). Body fat percentage was significantly associated with BMI $(p<0.001)$, WC $(p<0.001)$, WHR $(p=0.026)$, MUAC $(p<0.001)$ and $\operatorname{SMM}(p<0.001)$.

\section{DISCUSSION}

The present study investigated body composition and the risk for NCDs in adolescent swimmers training competitively in Trinidad and Tobago, based on various anthropometric parameters. Normal weight (ie between the $3^{\text {rd }}$ and $85^{\text {th }}$ percentiles for age) was observed in the majority of the swimmers; this may be attributed to their regular participation in swimming. These findings were similar to the results of a study conducted by Juzwiak et al which evaluated the body composition and dietary intake of 44 adolescent tennis players (46). The researchers found that the majority of the athletes in their study were within normal weight. Similarly, in a study by Gibson et al which evaluated the nutrition status of junior elite female soccer athletes, the researchers also found that the majority of the athletes in their study were within normal weight (47).

A comparison of BMI with WHO standards revealed that most swimmers were within the recommended range for adolescent athletes and therefore were at low

Table 3: Distribution of the swimmers using the cut-off points for anthropometric variables from specified groups

\begin{tabular}{llrr}
\hline Anthropometric variable & $\begin{array}{l}\text { Cut-off } \\
\text { description }\end{array}$ & $\begin{array}{r}\text { Female } \\
(\mathbf{n = 9 8})\end{array}$ & \multicolumn{1}{c}{$\begin{array}{c}\text { Male } \\
(\mathbf{n}=\mathbf{1 2 2}) \\
\mathbf{n}(\mathbf{\%})\end{array}$} \\
\hline Body mass index $^{1}$ & Underweight & $3(1.4)$ & $1(0.5)$ \\
& Normal weight & $72(32.7)$ & $86(39.1)$ \\
& Overweight & $17(7.7)$ & $22(10.0)$ \\
& Obese & $6(2.7)$ & $13(5.9)$ \\
& Low risk & $95(43.2)$ & $120(54.6)$ \\
Waist circumference ${ }^{2}$ & High risk & $3(1.4)$ & $2(0.9)$ \\
& Under fat & $8(4.0)$ & $27(13.6)$ \\
Body fat percentage $^{3}$ & Normal fat & $52(26.3)$ & $57(28.8)$ \\
& Over fat & $21(10.6)$ & $11(5.6)$ \\
& Obese & $13(6.6)$ & $9(4.5)$ \\
& Normal weight & $13(5.9)$ & $11(5.0)$ \\
$\begin{array}{l}\text { Mid-upper arm } \\
\text { circumference }\end{array}$ & Overweight/Obese & $85(38.6)$ & $111(50.5)$ \\
\hline
\end{tabular}

${ }^{1}$ World Health Organization $(41,42)$.

${ }^{2}$ Fernández et al (43).

${ }^{3}$ McCarthy et al (44).

${ }^{4}$ Mazicioğlu et al (33). risk for developing NCDs. However, $17.7 \%$ and $8.6 \%$ of the swimmers were considered overweight and obese, respectively, which suggested that the swimmers may have a high percentage of muscle mass since only five swimmers had a high WC, which put them at risk for developing NCDs. In a study which assessed the accuracy of BMI as a measure of percentage fat in college athletes and non-athletes, Ode et al concluded that BMI incorrectly classified athletes with normal body fat as overweight and that separate standards should be established for athletic populations (48). Therefore, the BMI results of the present study should be viewed with caution since BMI measures excess weight rather than excess fat and hence should not be used alone as a diagnostic tool to assess health but rather as an indicator of potential health problems. Our study showed that BMI and BFP were statistically significantly associated. Ochiai et al (26) also demonstrated that BMI and adiposity were notably related and may be useful in identifying excess body fat in adolescents and the increased risk for developing NCDs. It is important to note that although $\mathrm{BMI}$ is the most common measure of obesity, it does not take into account body composition (49). Additionally, it can be misleading in athletes with a high proportion of lean muscle mass (49). However, one limitation of the present study was that the hydration status of the athletes was not measured, which may have affected the accuracy of the results.

Sarria et al (50) and Himes (51) reported that WC and BMI had the same accuracy when identifying overweight/obesity in children. In contrast, researchers postulated that $\mathrm{WC}$ was a more accurate measure of the distrubution of body fat than BMI $(52,53)$. In that context, using the cut-off point for WC (43), we found that the majority of the swimmers were at 'low risk' for developing obesity and its co-morbidities, such as metabolic syndrome, Type 2 diabetes and cardiovascular

Table 4: Association between anthropometric variables using Chi-square

\begin{tabular}{lcccc}
\hline Variable & \multicolumn{2}{c}{ Gender } & \multicolumn{3}{c}{ Body fat percentage } \\
& Chi-square & $\boldsymbol{p}$ & Chi-square & $\boldsymbol{p}$ \\
\hline Body mass index & 2.877 & 0.411 & 96.177 & $<0.001^{*}$ \\
Waist circumference & 0.495 & 0.482 & 25.686 & $<0.001^{*}$ \\
Waist-to-hip ratio & 26.040 & $<0.001^{*}$ & 14.297 & $0.026^{*}$ \\
Mid-upper arm circumference & 1.009 & 0.315 & 38.832 & $<0.001^{*}$ \\
Body fat percentage & 13.926 & $0.003^{*}$ & - & - \\
Visceral fat & 0.443 & 0.506 & 6.724 & 0.081 \\
Skeletal muscle mass & 4.180 & 0.243 & 27.133 & $<0.001^{*}$ \\
\hline
\end{tabular}

${ }^{*} p<0.05$ 
diseases. Many studies have pointed out a strong positive relationship between $\mathrm{WC}$ and $\operatorname{BFP}(24,54)$. This was also supported by our study which showed a statistically significant association between WC and BFP. Additionally, Mehdad et al (24) identified WC as a good indicator for adiposity in adolescents. Both BMI and WC were endorsed by the American Heart Association as primary tools for measuring adiposity (55). However, WC is used less frequently. Waist circumference was also suggested to be the easiest and best indicator for screening for metabolic syndrome in adolescents (56) but may misjudge total and trunk fat $(24,57)$.

Swimmers who fell at or below the $2^{\text {nd }}$ percentile cutoff were considered under fat, between the $2^{\text {nd }}$ and $85^{\text {th }}$ percentiles were considered to have normal fat, between the $85^{\text {th }}$ and $95^{\text {th }}$ percentiles were considered over fat and those who fell at or above the 95th percentile were considered obese (44). Over half of the participants fell within the 'normal fat' category, which may have a positive effect on their health. Juzwiak et al also reported that participants in their study fell within the recommended body fat range (46). Our results showed that females had a higher body fat percentage when compared to males, which was expected, and that gender was statistically significantly associated with BFP (58). Body fat percentage plays a more important role in differentiating between healthy and obese individuals, as it has a greater ability to differentiate between lean mass and fat mass compared to BMI (59). Additionally, swimmers usually have a higher BFP when compared to athletes participating in other sporting disciplines (25).

A study conducted by Neovius et al showed that WHR was only weakly correlated to BFP, while BMI and $\mathrm{WC}$ showed strong positive correlations to $\mathrm{BPF}$ (54). Taylor et al (60) found that WC was better than WHR at predicting adiposity in adolescents. This was supported by our results which showed that WC had a stronger association with BFP than WHR did. Results also showed that WHR was statistically sigificantly associated with gender.

According to Dasgupta et al, MUAC is a good predictor of malnutrition in adolescents (61). Maziciolğlu et al concluded that it could be utilized in the screening of adolescents for obesity and fat distribution (33). In this study, MUAC was shown to be statistically significantly correlated to BFP. Mid-upper arm circumference is widely used as an indicator of severe and moderately acute undernutrition for children aged up to five years. However, researchers had identified and recommended MUAC as a variable tool to screen children and adolescents for obesity $(32,33,62,63)$. In our study, we found that the majority of swimmers were categorized as overweight/obese. This may have been due to the swimmers having a high muscle mass, causing their MUAC to be greater than that of the average adolescent. As such, MUAC may not be a suitable indicator of obesity for athletic adolescents. Additionally, the cut-off values did not take into account adolescents above the age of 17 years.

We concluded that based on BMI, WC, BFP and VF, the swimmers in this study had a healthy body composition and, therefore, were at low risk for developing NCDs. Although this study provided some baseline data for athletes, it is recommended that Trinidad and Tobago develop its own cut-off values for WC, BMI and MUAC for both athletes and non-athletes since anthropometric data for athletes in Trinidad and Tobago are non-existent.

\section{ACKNOWLEDGEMENTS}

The authors wish to thank Dr George Legall for his statistical assistance and the swimmers for participating in the study.

\section{REFERENCES}

1. James P. The challenge of childhood obesity. Int J Pediatr Obes 2006; 1: 7-10.

2. World Health Organization. Global status report on noncommunicable diseases 2010. Geneva, Switzerland: World Health Organization; 2011 (cited 2014 Aug 21). Available from: www.who.int/nmh/publications/ ncd_report2010/en.

3. World Health Organization. Reducing risks, promoting healthy life. World Health Report 2002. Geneva, Switzerland: World Health Organization; 2005.

4. Centers for Disease Control and Prevention, United States of America. Overweight \& obesity. Adult obesity facts (cited 2014 Sept 23). Available from: www.cdc.gov/obesity/data/adult.html.

5. Centers for Disease Control and Prevention, United States of America. Overweight \& obesity. Childhood obesity facts (cited 2014 Sept 23). Available from: www.cdc.gov/obesity/data/childhood.html.

6. Ogden CL, Carroll MD, Kit BK, Flegal KM. Prevalence of childhood and adult obesity in the United States, 2011-2012. JAMA 2014; 311: 806-14.

7. Ogden CL, Carroll MD, Curtin LR, McDowell MA, Tabak CJ, Flegal KM. Prevalence of overweight and obesity in the United States, 19992004. JAMA 2006; 295: 1549-55.

8. Ogden CL, Flegal KM, Carroll MD, Johnson CL. Prevalence and trends in overweight among US children and adolescents, 1999-2000. JAMA 2002; 288: 1728-32.

9. Lobstein T, Baur L, Uauy R. Obesity in children and young people: a crisis in public health. Obes Rev 2004; 5 (Suppl 1): 4-104.

10. Stemming the tide of non-communicable diseases in the Caribbean (a regional summit). CARICOM Heads of Government and Ministers of Health, September 2007, supported by the Pan American Health Organization and the Americas Bureau of the World Health Organization.

11. Department of Health and Human Services, Centers for Disease Control and Prevention, United States of America. The burden of chronic diseases and their risk factors; national and state perspectives. Atlanta: US Department of Health and Human Services; 2002.

12. Ezzati M, Lopez AD, Rodgers A, Murray CJL. Comparative quantification of health risks: global and regional burden of disease 
attributable to selected major risk factors. Geneva, Switzerland: World Health Organization; 2004.

13. World Cancer Research Fund/American Institute for Cancer Research. Food, nutrition, physical activity, and the prevention of cancer: a global perspective. Washington, DC, United States of America: American Institute for Cancer Research; 2007.

14. Freedman DS, Mei Z, Srinivasan SR, Berenson GS, Dietz WH. Cardiovascular risk factors and excess adiposity among overweight children and adolescents: the Bogalusa Heart Study. J Pediatr 2007; 150: $12-7$.

15. Whitaker RC, Wright JA, Pepe MS, Seidel KD, Dietz WH. Predicting obesity in young adulthood from childhood and parental obesity. N Engl J Med 1997; 337: 869-73.

16. Serdula MK, Ivery D, Coates RJ, Freedman DS, Williamson DF, Byers T. Do obese children become obese adults? A review of the literature. Prev Med 1993; 22: 167-77.

17. American Academy of Pediatrics. Policy statement: prevention of pediatric overweight and obesity. Pediatr 2003; 112: 424-30.

18. Tsiros MD, Olds T, Buckley JD, Grimshaw P, Brennan L, Walkley J et al. Health-related quality of life in obese children and adolescents. Int J Obes 2009; 33: 387-400.

19. Williams J, Wake M, Hesketh K, Maher E, Waters E. Health-related quality of life of overweight and obese children. JAMA 2005; 293: 70-6.

20. Proimos J, Klein JD. Noncommunicable diseases in children and adolescents. Pediatr 2012; 130: 379-80.

21. Rodriguez NR, DiMaro NM, Langley S. Position of the American Dietetic Association, Dietitians of Canada, and the American College of Sports Medicine: nutrition and athletic performance. J Am Diet Assoc 2009; 109: 509-27.

22. Baumgartner RN, Heymsfield SB, Roche AF. Human body composition and the epidemiology of chronic disease. Obes Res 1995; 3: 73-95.

23. Waldrop J. Early identification and interventions for female athlete triad. J Pediatr Health Care 2005; 19: 213-20.

24. Mehdad S, Hamrani A, El Kari K, El Hamdouchi A, Barakat A, El Mzibri $\mathrm{M}$ et al. Body mass index, waist circumference, body fat, fasting blood glucose in a sample of Moroccan adolescents aged 11-17 years. J Nutr Metab 2012; article ID 510458.

25. Pietrobelli A, Faith MS, Allison DB, Gallagher D, Chiumello G, Heymsfield SB. Body mass index as a measure of adiposity among children and adolescents: a validation study. J Pediatr 1998; 132: 204-10.

26. Ochiai H, Shirasawa T, Nishimura R, Morimoto A, Shimada N, Ohtsu $\mathrm{T}$ et al. Relationship of body mass index to percent body fat and waist circumference among school children in Japan - the influence of gender and obesity: a population-based cross-sectional study. BMC Public Health 2010; 10: 493.

27. Wilson ME, Harshfield GA, McLeod K, Hanevold C, Mackey L, Gillis D. P-560: gender differences in the relationship of body mass index to percent body fat in African-American youth. Am J Hypertens 2003; 16: (S1) 241A.

28. Balkau B, Deanfield JE, Després JP, Bassand JP, Fox KA, Smith SC Jr et al. International Day for the Evaluation of Abdominal Obesity (IDEA): a study of waist circumference, cardiovascular disease, and diabetes mellitus in 168,000 primary care patients in 63 countries. Circulation 2007; 116: $1942-51$.

29. Yusuf S, Hawken S, Ounpuu S, Dans T, Avezum A, Lanas F et al. Effect of potentially modifiable risk factors associated with myocardial infarction in 52 countries (the INTERHEART study): case-control study. Lancet 2004; 364: 937-52.

30. Pischon T, Boeing H, Hoffman K, Bergmann M, Schulze MB, Overvad $\mathrm{K}$ et al. General and abdominal adiposity and risk of death in Europe. $\mathrm{N}$ Engl J Med 2008; 359: 2105-20.

31. Jacobs EJ, Newton CC, Wang Y, Patel AV, McCullough ML, Campbell PT et al. Waist circumference and all-cause mortality in a large US cohort. Arch Int Med 2010; 170: 1293-301.

32. Cook S, Weitzman M, Auinger P, Nguyen M, Dietz WH. Prevalence of a metabolic syndrome phenotype in adolescents. Arch Pediatr Adolesc Med 2003; 157: 821-7.
33. Mazicioğlu MM, Hatipoğlu N, Öztürk A, Çiçek B, Üstünbaş B, Kurtoğlu $\mathrm{S}$. Waist circumference and mid-upper arm circumfernce in evaluation of obesity in children aged between 6 and 17 years. J Clin Res Pediatr Endocrinol 2010; 2: 144-50.

34. Klein S, Allison DB, Heymsfield SB, Kelley DE, Leibel RL, Nonas C et al. Waist circumference and cardiometabolic risk: a consensus statement from Shaping America's Health: Association for Weight Management and Obesity Prevention; NAASO, The Obesity Society; the American Society for Nutrition; and the American Diabetes Association. Am J Clin Nutr 2007; 85: 1197-202.

35. Colditz GA, Willett WC, Rotnitzky A, Manson JE. Weight gain as a risk factor for clinical diabetes mellitus in women. Ann Intern Med 1995; 122: 481-6.

36. Calle EE, Thun MJ, Petrelli JM, Rodriguez C, Heath CW Jr. Body-mass index and mortality in a prospective cohort of U.S. adults. N Engl J Med 1999; 341: 1097-105.

37. Pouliot MC, Despres JP, Lemieux S, Moorjani S, Bouchard C, Tremblay A et al. Waist circumference and abdominal sagittal diameter: best simple anthropometric indices of abdominal visceral adipose tissue accumulation and related cardiovascular risk in men and women. Am J Cardiol 1994; 73: 460-8.

38. Kissebah AH, Videlingum N, Murray R, Evans DJ, Hartz AJ, Kalkhoff RK et al. Relation of body fat distribution to metabolic complications of obesity. J Clin Endocrinol Metab 1982; 54: 254-60.

39. Chomtho S, Fewtrell MS, Jaffe A, Williams JE, Wells JC. Evaluation of arm anthropometry for assessing pediatric body composition: evidence from healthy and sick children. Pediatr Res 2006; 59: 860-5.

40. Marfell-Jones M, Olds T, Stew A, Carter L. International standards for anthropometric assessment. Australia: The International Society for the Advancement of Kinanthropometry; 2006.

41. World Health Organization. Growth reference. Simplified field tables. BMI-for-age girls and boys, 5 to 19 years (percentiles) (cited 2012 Nov 26). Available from: www.who.int/growthref/who2007_bmi_for_age_ field/en/index.html.

42. World Health Organization. BMI classification (cited 2012 Nov 28). Available from: http://apps.who.int/bmi/index.jsp?introPage=intro_3. html.

43. Fernández JR, Redden DT, Pietrolli A, Allison DB. Waist circumference percentiles in nationally representive samples of African-American, European-American, and Mexican-American children and adolescents. J Pediatr 2004; 145: 439-44.

44. McCarthy HD, Cole TJ, Fry T, Jebb SA, Prentice AM. Body fat reference curves for children. Int J Obes 2006; 30: 598-602.

45. Omron Healthcare. Omron instruction manual: full body sensor body composition monitor and scale, model HBF-510. Illinois, USA; 2008.

46. Juzwiak CR, Amanico OM, Vitalle MS, Pinherio MM, Szejnfeld VL. Body composition and nutritional profile of male adolescent tennis players. J Sports Sci 2008; 26: 1209-17.

47. Gibson JC, Stuart-Hill L, Martin S, Gaul C. Nutrition status of junior elite Canadian female soccer athletes. Int J Sport Nutr Exer Metab 2011; 21: $507-14$.

48. Ode JJ, Pivarnik JM, Reeves MJ, Knous JL. Body mass index as a predictor of percent fat in college athletes and nonathletes. Med Sci Sports Exerc 2007; 39: 403-9.

49. Etchison WC, Bloodgood EA, Minton CP, Thompson NJ, Collins MA, Hunter SC et al. Body mass index and percentage of body fat as indicators for obesity in an adolescent athletic population. Sports Health 2011; 3: $249-52$.

50. Sarría A, Moreno LA, García-Llop LA, Fleta J, Morellón MP, Bueno M. Body mass index, tricep skinfold and waist circumference in screening for adiposity in male children and adolescents. Acta Paediatrica 2001; 90: $387-92$.

51. Himes JH. Challenges of accurately measuring and using BMI and other indicators of obesity in children. Pediatrics 2009; 124 (Suppl 1): S3-22.

52. Brown P. Waist circumference in primary care. Prim Care Diabetes 2009; 3: 259-61.

53. Dagan SS, Segev S, Novikov I, Dankner R. Waist circumference vs body mass index in association with cardiorespiratory fitness in healthy 
men and women: a cross sectional analysis of 403 subjects. Nutr J 2013; 12: 12 .

54. Neovius M, Linné Y, Rossner S. BMI, waist-circumference and waisthip-ratio as diagnostic tests for fatness in adolescents. Int J Obes 2005; 29: 163-9.

55. Cornier MA, Després N, Grossniklaus DA, Klein S, Lamarche B, Lopez-Jimenez F et al. Assessing adiposity: a scientific statement from the American Heart Association. Circulation 2011; 124: 1996-2019.

56. Rodríquez G, Moreno LA, Blay MG, Blay VA, Garagorri JM, Sarria A et al. Body composition in adolescents: measurements and metabolic aspects. Int J Obes Relat Metab Discord 2004; 28 (Suppl 3): S54-8.

57. Wang H, Story RE, Venners SA, Wang B, Yang J, Li Z et al. Patterns and interrelationship of body-fat measures among rural Chinese children aged 6 to 18 years. Pediatr 2007; 120: e94-101.

58. USA Swimming and The U.S. Ski and Snowboard Association. The young athlete's body: physical development. Successful Sports Parenting, USA; 2006. Available from: www.nutmegaquatics.com/ ctnmeg/UserFiles/File/The\%20Young\%20Athlete's\%20Body\%20 Physical\%20Development.pdf.
59. Goonasegaran AR, Nabila FN, Shuhada NS. Comparision of the effectiveness of body mass index and body fat percentage in defining body composition. Singapore Med J 2012; 53: 403-8.

60. Taylor RW, Jones IE, Willians SM, Goulding A. Evaluation of waist circumference, waist-to-hip ratio, and the conicity index as screening tools for high trunk fat mass, as measured by dual-energy X-ray absorptiometry, in children aged 3-19 y. Am J Clin Nutr 2000; 72: 490-5.

61. Dasgupta A, Butt A, Saha TK, Basu G, Chattopadhyay A, Mukherjee A. Assessment of malnutrition among adolescents: can BMI be replaced by MUAC. Indian J Community Med 2010; 35: 276-9.

62. Cole TJ, Bellizzi MC, Flegal KM, Dietz WH. Establishing a standard definition for child overweight and obesity worldwide: international survey. BMJ 2000; 320: 1240-3.

63. Craig E, Bland R, Ndirangu J, Reilly JJ. Use of mid-upper arm circumference for determining overweight and overfatness in children and adolescents. Arch Dis Child 2014; 99: 763-6. 